\title{
ТЕХНОЛОГИЧЕСКИЕ ОРИЕНТИРЫ
}

МОНИТОРИНГА ГОТОВНОСТИ СТУДЕНТОВ-

МУЗЫКАНТОВ К ХУДОЖЕСТВЕННО-

ИНТЕРПРЕТАЦИОННОЙ ДЕЯТЕЛЬНОСТИ

\section{И. Е. Молоствова,}

Мордовский государственный педагогический институт имени М. Е. Евсевьева, г. Саранск, Республика Мордовия, Российская Федерация, 430007

Аннотация. B статье характеризуются требования, предъявляельле $\kappa$ человеку нового врелени, выражаюшиеся в необходилости его личностного салоразвития, полноценного раскрытия творческого потенииала. Определяется специфбка пробессиональной деятельности педагога-лузыканта как субьекта культурь, способного к установлению с обучающилися взаилодействия духовного уровня, которое базируется на актуализаиии творческого салосознания всех субъектов образовательного процесса. Автор расслатривает возложность технологизаиии процесса овладения педагогол-музыкантол художественно-интерпретационной деятельностью как необходилой составляющей его профбессиональной подготовки, начиная с разработки диагностики успешности овладения ею. С этой иелью вводится понятие «художественно-интерпретаиионная колпетентность педагога-лузыкантал и определяются этапь овладения ею: мотивационно-ориентировочный, процессуально-деятельностный и результативно-корректировочный. В статье предлагается развёрнутая характеристика этих этапов с точки зрения содержания и диагностики достижения соответствующего уровня. В соответствии с этил для диагностики процесса форлирования художественно-интерпретационной колпетентности автор предлагает уровневый принцип диагностики и прилерную систему заданий, выявляющих знания и уления, характеризуелье как стандартные, ключевые или ведущие.

Ключевые слова: гуманитарные иенности общества и культуры, художественная интерпретаиия, образовательнье технологии, культуросоответственное лузыкальное образование, творческий потенииал обучаюшихся.

Благодарности: Автор выражает глубокую благодарность заведующелу кафбедрой методологии и технологий педагогики музыкального образования Московского педагогического государственного университета, доктору педагогических наук, профбессору Эдуарду Борисовичу 
Абдуллину за постоянное внилание и заинтересованную поддержку в научно-исследовательской деятельности. Искренняя признательность - главнолу редактору журнала "Музыкальное искусство и образованиен, доктору педагогических наук, профбессору Елене Владилировне Николаевой за неоценилую полощь и важные советы в процессе подготовки статьи к публикации.

Для цитирования: Молоствова И. Е. Технологические ориентиры мониторинга готовности студентов-музыкантов к художественно-интерпретационной деятельности // Музыкальное искусство и образование. 2019. T. 7. № 1. C. 60-77.

\title{
TECHNOLOGICAL TERMS OF MONITORING THE READINESS OF MUSICIAN STUDENTS FOR ARTISTIC-INTERPRETATIONAL ACTIVITIES
}

\section{Irina Ye. Molostvova,}

Mordovian State Pedagogical Institute named after M. E. Evsevyev, Saransk, Republic of Mordovia, Russian Federation, 430007

\begin{abstract}
The article describes the requirements for a man of the new time, expressed in the need for his personal self-development, the full disclosure of creative potential. The specificity of the professional activity of a teachermusician as a subject of culture capable of establishing a spiritual level interaction with students is determined, which is based on the actualization of the creative self-consciousness of all subjects of the educational process. The author considers the possibility of the technologization of the process of mastering the teacher-musician artistic and interpretative activities as a necessary component of his professional training, starting with the development of diagnostics of the success of mastering it. For this purpose, the concept of "artistic and interpretational competence of a teacher-musician" is introduced, and the stages of mastering it are defined: motivational-indicative, proceduralactivity-related, and effective-corrective. The article proposes a detailed description of these stages in terms of content and diagnosis of the achievement of the appropriate level. In accordance with this, to diagnose the process of forming artistic and interpretative competence, the author proposes a level principle of diagnosis and an exemplary system of tasks that reveal knowledge and skills that are characterized as standard, key or leading.
\end{abstract}

Keywords: humanitarian values of society and culture, artistic interpretation, educational technologies, cultural and appropriate musical education, creative potential of students. 
Acknowledgements: The author is deeply grateful to the head of the Department of Methodology and Technology of Pedagogy of Music Education of the Moscow Pedagogical State University, Doctor of Pedagogical Sciences, Professor Edward B. Abdullin for his constant attention and interested support in research activities. Sincere appreciation to the Editorin-Chief of the bulletin "Musical Art and Education", Doctor of Pedagogical Sciences, Professor Elena V. Nikolaeva for invaluable help and important advice in the process of preparing an article for publication.

For citation: Molostvova I. Ye. Technological terms of monitoring the readiness of musician students for artistic-interpretational activities. Muzykal'noe iskusstvo $i$ obrazovanie = Musical Art and Education, 2019, vol. 7, no. 1, pp. 60-77.

\section{Проблема взаимодействия} художественного и технологического

\section{в профессиональной деятельности} педагога-музыканта

Цели и задачи современного профессионального образования ясно очерчивают необходимость формирования личности, готовой к саморазвитию, самообучению и самовоспитанию. Как никогда важными стали проблемы поиска путей актуализации учебной сало-деятельности, базирующейся на приоритете высоких гуманистических идеалов - свободы, плюрализма, радости творения. Последние отнюдь не предполагают анархию в процессе обучения. Напротив, ещё более важными становятся качества личности, связанные с самоорганизацией, рефрлекией и самооценкой. Следовательно, образование должно вооружить профессионала инструментами и механизмами автономного, но неконфрликтного бытия в постоянно эволюционирующем социокультурном пространстве. А значит, он должен обладать необходимыми для него технологиями осуществления той или иной деятельности, объективно обеспечивающими задан- ный результат, и одновременно системой диагностики осуществления процесса и его результата.

Для профессионального образования педагога эти тенденции ещё более актуальны. Педагог имеет дело с будущим; его деятельность связана со становлением человека, который через 5-10 лет станет активной единицей общества. А значит, ему необходимо стратегическое мышление, умение прогнозировать результат, актуальный для грядущего времени, предполагая этапы корректировки в соответствии с изменяющимися условиями.

В современном информационном мире непрерывно обновляются знания. Чтобы быть конкурентоспособным преподавателем, педагогу следует постоянно осваивать новые знания, сохраняя адекватный уровень профрессиональной компетентности, а следовательно, осуществлять диагностику этого соответствия и впоследствии управлять собственным обучением. Таким образом, обусловлена важность овладения приёмами самодиагностики и управления саморазвитием. При этом сложно переоценить роль принципа технологичности обучения, позволяющего правильно организовать 
вышеназванные процессы, способствуя одновременно максимальной реализации потенциала человека.

Вопрос о возможности взаимодействия искусства и технологии в процессе обучения искусству был поставлен ещё в прошлом веке. Однако до настоящего времени он остаётся в числе наиболее обойдённых вниманием из-за спорности обстоятельств этого взаимодействия. Вместе с тем В. Г. Маранцман заявляет о том, что если «гармония искусства предполагает некоторую упорядоченносты,, то и «общение с искусством требует соблюдения известных правил, открывающих засовы тяжких врат и дающих простор воображению читателя, зрителя, слушателя, личностной оценке художественного произведения» [1, с. 91]. Можно считать методологически важными следующие его слова: «Программа общения с искусством может быть представлена в виде цикла операций, каждая из которых имеет конкретную цель. Совокупность этих операций рождает интерпретацию художественного произведения» [Там же]. Следовательно, необходимо продумать названную деятельность с точки зрения её технологии.

Исследователь А. С. Мигунов, рассматривая проблему соотнесения технологии и искусства, находит общее для них начало в символизации (как в производственной области, так и в гуманитарном знании и художественном творчестве), а также в алгоритмизации соответствующих процессов. Вместе с тем он указывает: «Желание понять и объяснить слагае- мые искусства, а значит, отыскать его алгоритм, всегда присутствовало в эстетике. И всегда оно наталкивалось на значительные трудности, связанные и с тайной рождения художественного замысла, и с не менее таинственным процессом воплощения такого замысла в произведении искусства» [2, с. 14]. Таким образом, актуальной остаётся дилемма между стремлением «поверить алгеброй гармонию» и непостижимостью художественного творчества. Решение данной проблемы, как всегда, находится «где-то посередине», в той небольшой области, где пересекаются эстетика, искусствоведение, психология, социология, культурология и даже точные науки во главе с математикой ${ }^{1}$.

В связи с изложенным интересно высказывание отечественного пианиста и педагога Г. Г. Нейгауза: «Раздумывая об искусстве и науке, об их взаимных связях и противоречиях, я почему-то пришёл к выводу, что математика и музыка находятся на крайних полюсах человеческого духа, что этими двумя антиподами ограничивается и определяется вся творческая духовная деятельность человека и что между нили размещается всё, что человечество создало в области науки и искусства» [4, с. 14].

\section{Технологический подход к диагностике художественно- интерпретационной компетентности педагога- музыканта}

Педагог-музыкант по характеру своей деятельности априори является

1 Ярким примером единения музыки и математики является идея Ю. Г. Кона, в которой вычисления плотности созвучий с помощью математических методов соотносятся с эстетической категорией диссонантности, тесно связанной с психологией восприятия гармонического движения [3]. 
субъектом культуры, то есть осуществляет функции не только потребления и хранения художественных ценностей, заложенных в произведениях музыкального искусства, но и преобразования и трансляции. Поэтому один из важных критериев качества музыкального образования - готовность студента-музыканта к реализации себя как профессионала в социокультурно значимой деятельности художественной интерпретации. Художественная интерпретация музыки определяется нами как творческая деятельность человека по созданию авторской трактовки культурных смыслов, заключённых в произведении музыкального искусства.

Художественная интерпретация музыки является для педагога-музыканта генеральной деятельностью, охватывающей эмоционально-чувственные и иррационально-интуитивные психические процессы, культурно-исторические и музыкально-теоретические знания, аналитические умения, творческие навыки. Она обеспечивается соответствующей специальной компетентностью. Художественно-интерпретационная компетентность педагога-музыканта - это профессиональное интегральное качество личности, охватывающее комплекс знаний, способов действия, определённых отношений с привлечением внешних ресурсов, проявляющееся в готовности на их основе трактовать концепты, отношения и ценности, заключённые в произведении музыкального искусства. Анализ литературы позволил нам выработать следующий комплекс специальных quasi-компетенщий, обеспечивающих овладение художественно-интерпретационной деятельностью:
1) готовность понимать и выражать сущность художественной интерпретации музыкального произведения и её значение в профессиональной деятельности педагога-музыканта;

2) готовность творчески использовать художественную интерпретацию при словесной и исполнительской трактовке музыкального произведения;

3) готовность осуществлять транслящию интерпретированных культурных смыслов музыкального произведения в профессиональной деятельности.

Проблематика разработки технологии мониторинга готовности студентов-музыкантов $к$ художественно-интерпретационной деятельности, необходимой в подготовке педагога-музыканта, обладает своей спецификой, связанной с приоритетом художественных принципов познания. Texнологичность предполагает наличие целесообразных шагов, этапов, приводящих $\mathrm{\kappa}$ достижению поставленной цели. Критериями их целесообразности являются иерархичность и преемственность. Инновационно-педагогический аспект рассматриваемой в статье технологии выражается в отведении значительного места творчеству педагога и учащихся, проявлению их индивидуальных позиций.

Наше понимание художественной интерпретации музыки как деятельности, соответственно, говорит о необходимости применения деятельностного подхода, позволяющего проектировать путь от общей идеи к точно описанным конкретным действиям. С этой позиции мы выделили три этапа:

1) мотивационно-ориентировочный; 
2) процессуально-деятельностный;

3) результативно-корректировочный, предполагающий реализацию итогов работы в заданной музыкально-коммуникативной ситуации и построение перспективы дальнейших педагогических действий.

На каждом этапе осуществляется диагностика его составляющих.

\section{Диагностика художественно- интерпретационной компетентности на мотивационно- ориентировочном этапе}

Определение готовности студентов-музыкантов к художественно-интерпретационной деятельности на мотивационно-ориентировочнол этапе предполагает выявление следующих аспектов:

- эстетические, музыковедческие, художественно-критические знания;

- способность к понятийно-логическому и художественно-образному мышлению, осуществлению их синтеза;

- владение логикой музыкально-языковой системы конкретной музыкальной культуры с характерной для неё семантикой;

- навыки музыкально-аналитической деятельности по познанию материальной и идеальной структур произведения;

- наличие достаточного музыкально-интонационного запаса;

- способность к ассоциативночувственной работе;

- навыки интуитивно-иррационального постижения музыкального содержания;

- слухомоторные способности, различные виды музыкального слуха.
Комплексная диагностика позволяет сделать выводы о полученном студентом опыте - жизненном, культурном, художественном, музыкальном. По нашему мнению, именно этот опыт должен стать в первую очередь объектом пристального внимания как одно из исходных начал успешности художественно-интерпретащионной деятельности. Опыт - сложное личностное образование, включающее в себя:

1) опыт эмоциональных впечатлений от музыки (то есть совокупность - большую или меньшую произведений, которые остаются значимыми для того или иного субъекта в течение достаточно длительного времени) - слушательский;

2) опыт осмысления произведения музыкального искусства как продукта культуры - ментальный;

3) опыт музыкально-исполнительской деятельности (непосредственная реализация собственных творческих поисков в звучании) - исполнительский;

4) опыт размышления о музыке - концептуальныци, или интерпретационньй.

Важные критерии выявления опыта связаны с тем, какой след оставило в душе человека произошедшее с ним:

- насколько этот след оказался глубок, ярок;

- как это сопряжено с другими впечатлениями, а также с их количеством;

- насколько это впечатление личностно-рефлексивно осмысленно и переработано субъектом.

Наряду с этим важна и своеобразная предуготовленность индивида

\footnotetext{
1 Здесь и далее орфография и пунктуация в ответах респондентов частично изменены.
} 
к впечатлению, особое (можно сказать, мифологизированное) видение мира, при котором каждое (казалось бы, неактуальное) явление жизни замечается и становится личностно значимым. Поэтому важно выявление глубины запечатлённого в эмоционально-чувственной форме образа, степени его детализации и долговременности. Критериями впечатлительности, согласно материалам психологической литературы, являются:

- целостность охвата явлений;

- глубина эмоциональных реакций;

- число ярких впечатлений жизни;

- наличие синтезирующего мышления;

- выявленные области источника положительных и отрицательных ассоциаций.

Таким образом, опыт выступает одним из важных условий художественной интерпретации, обеспечивая уникальность познания студентом-музыкантом тех или иных музыкальных явлений. Эта уникальность обусловлена личным отношением индивида к различным сторонам реального мира.

В соответствии с названными выше четырьмя сферами индивидуального опыта (слушательского, ментального, исполнительского, концептуального) процессуально-деятельностный этап включает в себя также продвижение студента-музыканта по четырём качественным уровням художественно-интерпретационной компетентности.

Первый - периептивный - уровень предполагает трактовку студентом отдельного музыкального произведения, взятого вне контекстных связей, при опоре на актуализацию его эмоционально-чувственной сcреры. При этом важна целостность постижения музыкальных явлений. Она предполагает наличие более или менее осмысленного художественного образа, желание его воплотить и собственно воплощение в индивидуализированной форме. В связи с этим важно предоставление свободы учащимся в выражении себя, понимании музыки, в раскрытии внутреннего творческого потенциала. При восприятии музыки актуализируется процесс наблюдения за явлениями искусства, а изучаемые произведения становятся предметом обсуждения и анализа, и далее - частью духовного мира будущего педагога-музыканта, его повседневной жизни. Поэтому ещё один критерий диагностики этого уровня - вовлечённость в культурную жизнь общества, выражаемая в мотивации к осуществлению художественной интерпретации как социально значимой деятельности.

Второй - аналитико-синтетический - уровень связан с постижением студентом музыкального произведения как продукта художественной культуры с позиции его принадлежности к отдельному музыкальному жанру, авторскому стилю при актуализации аналитических умений, базирующихся на знаниях о системе средств музыкального языка. Здесь актуализируются познавательные операции, связанные с анализом устройства художественной целостности произведения, овладением или изобретением своих собственных познавательных операций, поиском и использованием необходимых знаний для углубления формирующегося интерпретаторско- 
го замысла. Критерий этого уровня овладение студентом операциональными навыками. Не утрачивающий связи с предыдущим, данный уровень предполагает детализацию сформированного в процессе музыкальной перцепции обобщённого образа в аналитических выводах.

Третий - художественно-творческий - уровень предполагает познание студентом музыкального произведения в контексте художественного направления, творческой школы, эпохи с использованием аналитикосинтетических умений, что воплощается в реализации познанного в собственной исполнительской редакции.

Четвёртый - концептуальный уровень связан с выявлением идейнообразного содержания музыкального произведения в соотнесении с современной интерпретатору культурой на основе сложившейся у него картины мира. Высший уровень художественно-интерпретационной компетентности направлен на становление музыканта-художника, музыканта-мыслителя. Здесь важнейшим критерием выступает концептуальность деятельности музыканта, проявление им собственного максимально уникального, творческого проявления мировоззренческого начала.

На каждом из уровней актуализируются соответствующие знания и умения - стандартные, ключевые и ведущие, необходимые для успешного освоения конкретного уровня. Стандартные связаны со способностью решать типовые для данного вида деятельности задачи. $\mathrm{K}$ таковым относятся знания и умения, получаемые обучающимися в традиционных музыкальных дисциплинах. Они являются необходимой базой лю- бой музыкальной деятельности, опирающейся в своём освоении на комплекс музыкальных способностей. Ключевые знания и умения выражаются в способности решать инновационные задачи, поскольку каждое произведение ставит перед слушателем новые вопросы. Это обусловлено неповторимостью художественного образа, постижение которого выражается в уникальной трактовке. Ведущие знания и умения предполагают способность к созданию новых видов профессиональной деятельности. Они связываются с профрессиональнопредметной сферой. Так, например, педагог-музыкант адаптирует результаты художественной интерпретации музыки к определённым социокультурным условиям.

\section{Система уровневых заданий на процессуально-деятельностном этапе диагностики художественно- интерпретационной компетентности}

Для разработки диагностики процесса формирования художественно-интерпретационной компетентности нами выбрана уровневая система заданий, исходящая из уровневой же модели формирования названной компетентности и являющаяся одной из актуальных педагогических идей современного гуманитарно ориентированного образования. Выполнение заданий требует интонационно-художественного прочтения музыки, направленного на поиск художественной идеи произведения и апеллирующего к личностному ассоциативно-чувственному общему и музыкальному опыту студента-музыканта, стимулирующего его самостоятельность, творческую ини- 
циативу при работе с музыкальным материалом.

Важными фракторами успешности художественной интерпретации музыки являются:

- целостное восприятие музыкального произведения, предшествующее непосредственной интерпретации;

- опора на знания о музыкально-языковых формах (музыкальных знаках), служащих проводниками художественного смысла и побудителями ассоциативной деятельности познающего;

- сорормированность навыков распознавания элементов музыкальной речи;

- трактовка воспринятых элементов музыкальной речи при обязательной контекстности их художественного значения (контексты эпохи, жанра и стиля, художественной коммуникации изучаемого произведения, музыкально-речевого фрункционирования конкретного элемента музыкального текста и его культурно-исторической трансформации).

Задания предполагают тесное взаимодействие художественно-образного и рационально-логического мышления. Поэтому важным условием их выполнения является словесная аргументация (в письменной форме) принятого интерпретаторского решения. Студентам-музыкантам предоставляется выбор формы письменной работы: очерк, текст беседы или лекции, критический отзыв, изложение впечатлений от прослушанной музыки, сказка или история мифологического характера, аналитический разбор, небольшое эссе и т. д. Написанные тексты озвучиваются и впоследствии коллективно обсуждаются. Важный момент такого обучения - диалоговый характер взаимодействия преподавателя и обучающихся. В таком случае будущий педагог-музыкант воспринимает себя в качестве субъекта образовательного процесса, в котором он вступает на уровень межличностных, coтруднических отношений с преподавателем и другими учащимися. В результате этого осуществляется личностный рост всех участников.

В плане реализации данных позиций представляется интересным предложение В. П. Рябцева об использовании в образовательном процессе культурных сценариев. Исследователь рассматривает их как форму реализации культурологического подхода к профрессионально-педагогическому образованию, представляющую собой «общий план, очерчивающий общие контуры профессионального поведения в культурном контексте», на основе которых создаются «индивидуальные сценарии - индивидуальные траектории образования» [5, c. 210]. В этом случае реализуется контекстное обучение (А. А. Вербицкий) [6], предполагающее моделирование предметного и социального содержания усваиваемой профессиональной деятельности с помощью системы различных форм, методов и средств обучения и опирающееся на три основных источника: 1) предметный и социальный контекст; 2) деятельностную теорию, 3) формы и методы активного обучения.

В целом задания позволяют выявить уровень приобретённых навыков вербализации собственной точки зрения. При этом актуализируется внутренний мир личности обучающегося, устанавливается органическая взаимосвязь между выводами о произведении логико-аналитического 
характера и художественной рефлексией, опирающейся на индивидуальный общекультурный, художественный и исполнительский опыт. Содержание заданий в наиболее общих чертах отражает этапы музыкальнопознавательного процесса (от наиболее обобщённого восприятия через выявление значимых элементов музыкальной речи к осознанию художественного мира произведения):

1. Эмоциональное содержание музыки.

2. Жанровая основа музыки.

3. Стилевая основа музыки.

4. Художественно-образная и идейная концепция музыкального произведения.

Алгоритмизированность заданий выражается в конкретной формулировке этапов их выполнения, последовательность которых позволяет достичь заданной определённым компетентностным уровнем степени понимания музыки.

Задание I. Элоциональное содержание музыки

(периептивный уровень

художественно-интерпретаиионной

колпетентности музыканта)

Цель: создание эмоционально-образной характеристики музыкального произведения.

Результат: словесный ряд (или словосочетания), последовательно отражающий эмоции, чувства, переживания, ассоциации, вызванные музыкой.

Методическое обеспечение ${ }^{1}$ :

- словарь эстетических эмоций [7];

- словарь прилагательных, связанных с характеристикой разных типов движения;
- словарь жестов [8];

- список цветов;

- список геометрических форм;

- словарь архетипов [9].

Алгоритм:

1. Дайте эмоционально-образную характеристику прослушанной музыки, выразив её в цепочке слов или словосочетаний (с использованием вышеназванных словарей).

2. Опишите собственные ассоциации и представления, возникшие в ходе прослушивания данного произведения.

3. Определите ведущие смысловые элементы музыкального текста (музыкально-тематические образования) и охарактеризуйте их эмоционально-образное содержание, а также степень выразительного контраста.

4. Персонифицируйте ваши чувственные впечатления в архетипическом имени.

5. Выявите музыкально-выразительные средства (тема, регистр, лад, динамика, тембр) и определите их роль в организации художественного смысла конкретного музыкально-тематического образования.

6. Сравните произведение с известными вам аналогичными по содержанию произведениями живописи, литературы, других видов искусства; сделайте выводы о сходстве и различии эмоџионально-выразительных качеств.

7. Сопоставьте музыкальные выразительные средства со средствами других искусств; определите, можно ли провести между ними какие-либо аналогии (ответ обоснуйте).

8. Составьте небольшой словесный парафраз, раскрывающий эмо-

\footnotetext{
1 Данные методические материалы могут использоваться и на последующих уровнях.
} 
ционально-образное содержание музыки.

9. Исполните произведение (фрагмент) в соответствии с выработанными представлениями о нём.

Задание II. Жанровая основа музыки (аналитико-селантический уровень художественно-интерпретационной колпетентности музыканта)

Цель: выявление музыкальноязыковой и жанровой основы музыкального произведения.

Результат: словесный аналитический текст.

Методическое обеспечение:

- словарь музыкальных жанров.

Алгоритм:

1. Определите жанровую основу произведения, выделив жанровый комплекс на основании предложенной таблицы жанров ${ }^{1}$.

2. Выявите жанровые музыкально-выразительные средства, определите их роль в создании художественного смысла.

3. Охарактеризуйте взаимосвязь образного содержания произведения и избранного композитором жанра (или жанров, если музыка основывается на нескольких).

4. Проведите анализ метроритмической организащии мелодии, выделив и охарактеризовав при этом элементы, типичные для данного жанра.

5. Проанализируйте характер взаимодействия данного жанра и мелодической линии, определите выразительное значение их соотнесения.

6. Охарактеризуйте жанровую специфику фрактуры.

7. Суммируйте все музыкальные средства, характерные для рассмат- риваемого жанра (жанровый комплекс), и определите типичность музыки для данного жанра.

8. Исполните произведение (фрагмент) в соответствии с выработанными представлениями о нём.

Задание III. Стилевая основа музыки (художественно-творческий уровень художественно-интерпретаиионной компетентности музыканта)

Цель: характеристика музыкального произведения в контексте художественного направления, творческой школы, эпохи создания.

Результат: текст, выражающий интерпретаторский замысел, исполнение музыкального произведения.

\section{Алгоритм:}

1. Выделите комплекс выразительных средств, характерных для данного авторского стиля (или стиля соответствующего художественного направления, нащиональной школы).

2. Определите склад музыки (тип фактуры), свяжите выводы с исторической эпохой, к которой принадлежит произведение.

3. Выявите стилевую специфику (ладово-интонационную, метроритмическую и синтаксическую) организации мелодии, её воздействие на выразительность и смысловое содержание музыки.

4. Сделайте общие выводы о структуре и фрункциональной принадлежности аккордов.

5. Сравните мелодику и гармонию пьесы и сделайте выводы о связанных с этим отличительных стилевых чертах произведения.

6. Раскройте драматургию музыкального произведения в мифологизированном «сюжете».

\footnotetext{
1 При выполнении задания испытуемым предъявляется таблица жанров.
} 
7. Охарактеризуйте взаимосвязь конкретного стиля (исторического, национального или авторского) и художественно-образного содержания пьесы; выводы свяжите с музыкально-исполнительскими задачами.

8. Исполните произведение (ррагмент) в соответствии с выработанными представлениями о нём.

\section{Задание IV. Художественно-образная и идейная кониепиии музыкального произведения (концептуальный уровень} художественно-интерпретационной колпетентности музьканта)

Цель: выявление концептуального содержания музыкального произведения в соотнесении с современной интерпретатору культурой.

Результат: творческая интерпретация музыкального произведения.

Алгоритм:

1. Охарактеризуйте связь содержания произведения с действительностью - конкретными жизненными явлениями или чувствами, эмоциями и мыслями человека.

2. Выявите степень обобщённости образа.

3. Определите наличие авторского отношения к отражаемым явлениям.

4. Выявите, в чём заключается индивидуализированность созданного композитором образа.

5. Опишите музыкальные выразительные средства, способствующие созданию художественного эффоекта.

6. Сдрормулируйте выводы относительно сделанной творческой находки композитора.

7. Раскройте драматургию музыкального произведения в мифологизированном «сюжете».
8. Определите культрную ценность произведения с позищии современности.

9. Исполните произведение (фрагмент) в соответствии с выработанными представлениями о нём.

Как видно из представленных заданий, их содержание нелокально: компоненты их переплетаются между собой, либо предвосхищая будущий уровень, либо синтезируя ранее использованные знания и навыки. Выполнение заданий включает в себя исполнительскую и словесную интерпретацию предложенных музыкальных произведений. Последовательность словесной и исполнительской интерпретаций определяется самим студентом. Важными критериями при этом являются: 1 - установление ораторского и исполнительского взаимодействия с аудиторией; 2 - адекватное моделирование ситуации непосредственного общения со слушателями; 3 - пройденный путь открьтия: музыкального содержания, творческого метода композитора, демонстрации собственной интерпретаторской позиции.

\section{Результативно-корректировочный этап диагностики}

На данном этапе осуществляется диагностика эфрфективности формирования художественно-интерпретационной компетентности, обусловленная спецификой и задачами каждого её отдельного уровня. Оценка результатов художественно-интерпретационной деятельности позволяет задавать приоритетные направления индивидуального развития отдельного студента по каждому предмету или предметному циклу (на основе анализа имеющихся и недостающих знаний и умений). Это выражается в следую- 
щих стадиях педагогического взаимодействия со студентами:

1. Анализ сфрормированного комплекса умений и навыков, соответствующих определённому уровню художественно-интерпретационной компетентности (в случае, если исследуются второй и более высокие уровни, оцениваются составляющие художественно-интерпретационной компетенции нижележащих уровней).

2. Разработка индивидуальных планов личностного и профессионального развития студентов и формирование мини-групп.

3. Планирование и реализация мероприятий по обучению и развитию как отдельного студента, так и учебной группы. Возможно также и стратегическое планирование по циклу дисциплин.

4. Оценка эффрективности реализации индивидуальных и групповых планов развития.

В числе целей рассматриваемого этапа - вовлечение студентов в музыкально-культурную жизнь общества, становление понимания музыки как обязательного элемента духовной ценности личности, привитие вкуса. Контрольные задания, направленные на осуществление исполнительской и словесной художественной интерпретации музыки, по своему содержанию связаны с методом ситуационных упражнений. Обучаемому предлагается решить поставленные задачи, учитывая контекст предполагаемой деятельности. Важно, что при этом формируется понимание студентами назначения осуществляемой художественно-интерпретационной деятельности, связанной с приобретаемой ими музыкально-педагогической профессией.
Исходя из положения о музыканте как о субъекте культуры, как об активном участнике социокультурных коммуникативных процессов, следует учитывать, что важным аспектом выполнения заданий является установление культуросообразного взаимодействия с аудиторией. Таким образом студент приобщается к миру художественных ценностей, заложенных в музыкальном произведении, к переживаниям и пониманию мира композитором, который в своём творении передаёт другим участникам художественной коммуникации собственное эмоционально-ценностное отношение к жизненным и природным явлениям, к разнообразным связям людей между собой. В результате актуализируются такие профессионально важные качества будущего педагога-музыканта, как:

- умение эмоционально заряжать собственным исполнением музыки слушателей, доносить до них художественную идею произведения и своё понимание её;

- способность увлечь рассказом о музыке, давая ей личностную оценку, проявляя способность к свободному общению с аудиторией по поводу конкретного произведения.

Выполнение осуществляется с учётом конкретной музыкально-коммуникативной ситуации (подготовить и провести беседу, рассказать о музыкальном произведении, выступить с вводным словом к прослушиванию или разучиванию произведения, с аннотацией к самостоятельно исполняемой музыке, партитурой вопросов после прослушивания, разработать моноурок в общеобразовательной школе и т. п.). 
Студент может сам выбрать тип предполагаемой аудитории (академический салон, коллега по ансамблю, ученик, класс, друзья, родители учащихся), после чего осуществляет анализ возрастных и социокультурных особенностей предполагаемой аудитории, определяет наиболее эффрективную форму устного преподнесения конкретного материала (целый урок или его фррагмент, беседа, лекция, диалог, игра, массовые формы музыкально-просветительной работы), задачи (педагогические, просветительные или другие) и соответствующую художественную ценность отбираемого музыкального материала. Далее следуют осмысление обучающимся проблемы, постановка художественноинтерпретационных задач, поиск путей их решения (что обусловливается тем или иным социокультурным контекстом), а также переход к самостоятельному решению задачи.

Природные задатки и способности, сформированные умения и навыки, комплекс имеющихся у студентов знаний не являются исчерпывающими для полной и адекватной диагностики художественно-интерпретационной компетентности. Важнее те стороны внутреннего мира личности, которые позволяют человеку называть себя музыкантом, то есть социально и культурно значимой единицей человеческого сообщества, играющей роль хранителя и транслятора духовных ценностей, заложенных в произведениях музыкального искусства. В связи с этим необходима диагностика личностных показателей:

- активной музыкально-познавательной позиции (проявление отношения к музыке как к художественно-содержательному явлению, самостоятельности музыкально-познавательной деятельности);

- стремления к самореализации в музыкальной деятельности (ясное понимание своего места в музыкальной культуре, наличие и частота исполнительских и лекторско-просветительских выступлений, участие в жизни образовательного учреждения);

- отношения к художественной интерпретации как к средству реализации творческой индивидуальности музыканта.

Данные критерии определяются с помощью анкетирования. Целесообразно использование двух видов анкет. Первая анкета открытого типа направлена на выявление понимания студентами-музыкантами термина «интерпретация» и значения интерпретации в жизни и искусстве; осознания степени важности владения интерпретацией исполнителем, музыковедом, преподавателем, места интерпретации в обучении музыканта и его профессиональной деятельности, комплекса знаний, умений и навыков, необходимых для осуществления художественной интерпретации музыкального произведения.

Вторая анкета закрытого типа охватывает вопросы, связанные с выявлением роли и места интерпретации в целостной музыкальной деятельности реципиента, в частности:

- сколько времени в сутки в среднем посвящается музыкальной деятельности: какую часть времени музыкальных занятий (в процентном соотношении) занимают работа над репертуаром, изучаемым в исполнительском классе, чтение с листа произведений, выбранных по собственному желанию, различные фрормы творческого музицирования (подбор 
музыки или аккомпанемента к вокальной музыке, сочинение собственных композиций и пр.), чтение музыкальной популярной, научнопопулярной и специальной литературы, слушание музыки, выполнение различных упражнений, как исполнительских, так и связанных с освоением музыкальной теории, профессиональное взаимодействие с коллегами, сокурсниками и др.;

- какой из видов музыкальной деятельности доставляет наибольшее удовольствие;

- что даёт занятие излюбленной музыкальной деятельностью (новые впечатления, возможность обогатить свою жизнь, развиваться благодаря более широким и глубоким знаниям о музыкальном искусстве, целенаправленное собственное музыкально-профессиональное развитие, возможность глубже познать суть музыкальных явлений, совершенствовать профрессиональные навыки и умения, помогающие решать различные задачи в реальной практической деятельности, открывать что-то новое);

- к чему проявляется большее стремление (к художественному взаимодействию $\mathrm{c}$ другими людьми в рамках коллективной музыкальной деятельности, к публичной демонстрации своих достижений, к собственному развитию, выражающемуся в какой-либо публичной музыкальной деятельности;

- какой мотив наиболее весом в плане музыкальной самореализации (публичный успех, повышение сощиального статуса, перспектива быть лучшим среди своих коллег, сокурсников, признание и одобрение результатов работы, ответственность за качество выполняемой деятельно- сти, возможность творческого, профессионального роста, возможность художественного межличностного контакта).

Специфика художественной интерпретации музыки как творческой деятельности, направленной на дальнейшую социокультурную реализацию, обусловливает сложность её оценки. Традиционная 5-балльная система не позволяет объективно оценить качество выполнения задания. Представляется целесообразной экспертная оценка по 10-балльной шкале. В учебных целях оценивание осуществляется всеми участниками коммуникативного процесса (членами учебной группы) с последующим выведением среднего балла по предлагаемым критериям:

1) личностное раскрытие содержания музыкального произведения;

2) степень полноты постижения авторского замысла (знание творческих приоритетов композитора, художественных ориентиров его деятельности этого периода и др.);

3) артистизм в донесении до публики сделанных выводов, их соответствие выбору предполагаемой аудитории;

4) уравновешенное сочетание познавательного и художественно-эстетического аспектов предъявленного материала;

5) детализированность интерпретаторской аргументации, наличие связи между явлениями музыки и личными впечатлениями выступающего;

6) адекватность словесной характеристики музыки и её исполнения;

7) успешность коммуникативного взаимодействия, проявляющегося 
в художественном эффректе, положительном отклике аудитории.

Оценочные критерии включают в себя определение социокультурной эфрфективности (результативности) и степень уникально-творческого подхода к созданию и реализации интерпретаторского замысла. При этом, конечно же, учитывается и степень адекватности музыкальному произведению осуществленных интерпретаторских усилий.

\section{Заключение}

Таким образом, диагностические процедуры со специально разработанными критериями, показателями и инструментарием измерения результатов деятельности могут быть технологизированы. Рассмотренная этапность мониторинга реализации формирования художественно-интерпретационной компетентности обладает сквозным характером. Это способствует эфрфективному освоению названных компетенций, а следовательно, создаёт предпосылки успешного профессионального роста педагога-музыканта. Изложенное в статье позволяет выделить следующие технологические ориентиры мониторинга эффективности формирования художественно-интерпретационной компетентности будущего педагогамузыканта:

- сочетаемость и взаимодополняемость её уровней;

- наличие стандартизированных заданий, выполняемых по заданному алгоритму;

- учёт всех ранее освоенных уровней, благодаря чему возникает системность освоения компетентности;

- на всех уровнях освоения компетентности все задания оценивают- ся по одной системе критериев, что позволяет сопоставлять результаты.

Систематичность мониторинга невозможна без перманентного консультирования студентов. Она помогает им правильно оценить свои способности, умения и навыки, разработать стратегию личностного развития и обеспечить необходимые для этого условия. В результате самостоятельно осмысливаются следующие проблемы:

- отсутствие определённой составляющей художественно-интерпретационной компетентности того или иного уровня;

- постановка задач собственного развития;

- выбор учебной деятельности, наиболее эфрфективной для решения поставленной задачи.

Для практической реализации системы мониторинга эфрфективности формирования художественноинтерпретационной компетентности необходимы соответствующие коррективы в методических документах. Они должны содержать набор составляющих художественно-интерпретационной компетентности.

В этом плане целесообразно введение интерпретационного практикума, который будет иметь отдельный оценочный критерий, учитываемый при отчётности наряду с теоретическими знаниями и частнопрактическими умениями. Это позволит сбалансировать образовательный и профессиональный аспекты подготовки, органично соотнести фундаментальную и практическую составляющие процесса обучения, что обусловит взаимодействие обучения и практической профрессиональной деятельности педагога-музыканта в социуме. 


\section{БИБЛИОГРАФИЯ}

1. Мараниман В. Г. Интерпретация художественного произведения как технология общения с искусством // Литература в школе. 1998. № 8. С. 91-98.

2. Мигунов А. С. Эстетика, искусство и современные гуманитарные технологии // Вестник Московского университета. Сер. 7. Философия. 2011. № 3. С. 3-25.

3. Кон Ю. Г. Об одном свойстве вертикали в атональной музыке // Музыка и современность. Вып. 7. М.: Музыка, 1971. С. 294-315.

4. Нейгауз Г. Г. Об искусстве фортепианной игры. М.: Музыка, 1988. 240 с.

5. Рябиев В. П. Теоретические основы культурологического подхода к профессиональному педагогическому образованию: дис. .... д-ра культурологии. 24.00.01. Краснодар, 2006. 288 с.

6. Вербицкий А. А. Контексты содержания образования. М.: Альфа, 2003. 80 с.

7. Ражников В. Г. Диалоги о музыкальной педагогике. М.: Классика-XXI, 2004. 136 с.

8. Флягина, Т. А. Проектирование человеко-компьютерного взаимодействия, основанного на жестах : Квалификационная работа на степень магистра наук по направлению «Математика, прикладная математика». Екатеринбург. 2010. URL: http://www.cv.imm.uran.ru/ uploads/f1/s/0/299/basic/353/487/m_1.0.1.pdf (дата обращения: 21.01.2019).

9. Марк М., Пирсон К. Герой и бунтарь. Создание бренда с помощью архетипов. СПб.: Питер, 2005. $336 \mathrm{c}$.

Поступила 05.02.2019; принята к публикации 27.02.2019.

\section{Об ав торе:}

Молоствова Ирина Евгеньевна, доцент кафедры музыкального образования и методики преподавания музыки Мордовского государственного педагогического института имени М. Е. Евсевьева (ул. Студенческая, д. 11А, г. Саранск, Республика Мордовия, 430007), кандидат педагогических наук, доцент, mie7@rambler.ru

Автором прочитан и одобрен окончательный вариант рукописи.

\section{REFERENCES}

1. Marancman V. G. Interpretaciya hudozhestvennogo proizvedeniya kak tekhnologiya obshcheniya $\mathrm{s}$ iskusstvom [Interpretation of a work of art as a technology to communicate with art]. Literature in school, 1998, no. 8, pp. 91-98 (in Russian, abstract in English).

2. Migunov A. S. Estetika, iskusstvo i sovremennye gumanitarnye tekhnologii [Aesthetics, art and modern humanities]. Vestnik Moskovskogo universiteta $=$ Moscow University Bulletin. Series 7. Philosophy, 2011, no. 3, pp. 3-25 (in Russian, abstract in English).

3. Kon Yu. G. Ob odnom svojstve vertikali v atonal'noj muzyke [On one property of vertical in atonal music]. Muzyka i sovremennost' [Music and Modernity]. Issue 7. Moscow: Music Publ., 1971, pp. 294-315 (in Russian).

4. Nejgauz G. G. Ob iskusstve fortepiannoj igry [On the art of piano playing]. Moscow: Music Publ., 1988. 240 p. (in Russian).

5. Ryabtsev V. P. Teoreticheskie osnovy kul'turologicheskogo podhoda k professional'nomu pedagogicheskomu obrazovaniyu [Theoretical foundations of the culturological approach 
to professional pedagogical education]. Doctoral dissertation (Culturology): 24.00.01. Krasnodar, 2006. 288 p. (in Russian).

6. Verbitsky A. A. Konteksty soderzhaniya obrazovaniya [Contexts of educational content]. Moscow: Alpha Publ., 2003. 80 p. (in Russian).

7. Razhnikov V. G. Dialogi o muzykal'noj pedagogike [Conversations about music pedagogy]. Moscow: Klassik-XXI Publ., 2004. 136 p. (in Russian).

8. Flyagina T. A. Proektirovanie cheloveko-komp'yuternogo vzaimodejstviya, osnovannogo na zhestah [Designing human-computer interaction based on gestures]. Ekaterinburg, 2010. Available at: http://www.cv.imm.uran.ru/uploads/f1/s/0/299/basic/353/487/m_1.0.1.pdf (accessed: 21.01.2019) (in Russian).

9. Mark M., Pirson K. Geroj i buntar'. Sozdanie brenda s pomoshch 'yu arhetipov [Hero and rebel. Creating a brand with archetypes]. St. Petersburg: Piter Publ., 2005. 336 p. (in Russian).

Submitted 05.02.2019; revised 27.02.2019.

About the author:

Irina Y. Molostvova, Associate Professor at the Department of Music Education and Methods of Teaching Music, Mordovia State Pedagogical Institute named after M. E. Evsevyev, Student Street, 11A, Saransk, Republic of Mordovia, 430007), PhD in Pedagogy, Associate Professor, mie7@rambler.ru

The author has read and approved the final manuscript. 